\title{
The Influence of E-Service Quality Toward Online Shopping Behaviour Amongst UiTM Students in Malaysia
}

Rozita Mengen, Mohd Safwan Ramli, Nur Hidayah Ayob, Zaidatul Nadhirah Roslan

To Link this Article: http://dx.doi.org/10.6007/IJARBSS/v11-i10/10192

DOI:10.6007/IJARBSS/v11-i10/10192

Received: 10 August 2021, Revised: 02 September 2021, Accepted: 24 September 2021

Published Online: 05 October 2021

In-Text Citation: (Mengen et al., 2021)

To Cite this Article: Mengen, R., Ramli, M. S., Ayob, N. H., \& Roslan, Z. N. (2021). The Influence of E-Service Quality Toward Online Shopping Behaviour Amongst UiTM Students in Malaysia. International Journal of Academic Research in Business and Social Sciences, 11(10), 175-189.

Copyright: (c) 2021 The Author(s)

Published by Human Resource Management Academic Research Society (www.hrmars.com)

This article is published under the Creative Commons Attribution (CC BY 4.0) license. Anyone may reproduce, distribute, translate and create derivative works of this article (for both commercial and non-commercial purposes), subject to full attribution to the original publication and authors. The full terms of this license may be seen

at: http://creativecommons.org/licences/by/4.0/legalcode

Vol. 11, No. 10, 2021, Pg. 175 - 189

Full Terms \& Conditions of access and use can be found at http://hrmars.com/index.php/pages/detail/publication-ethics 


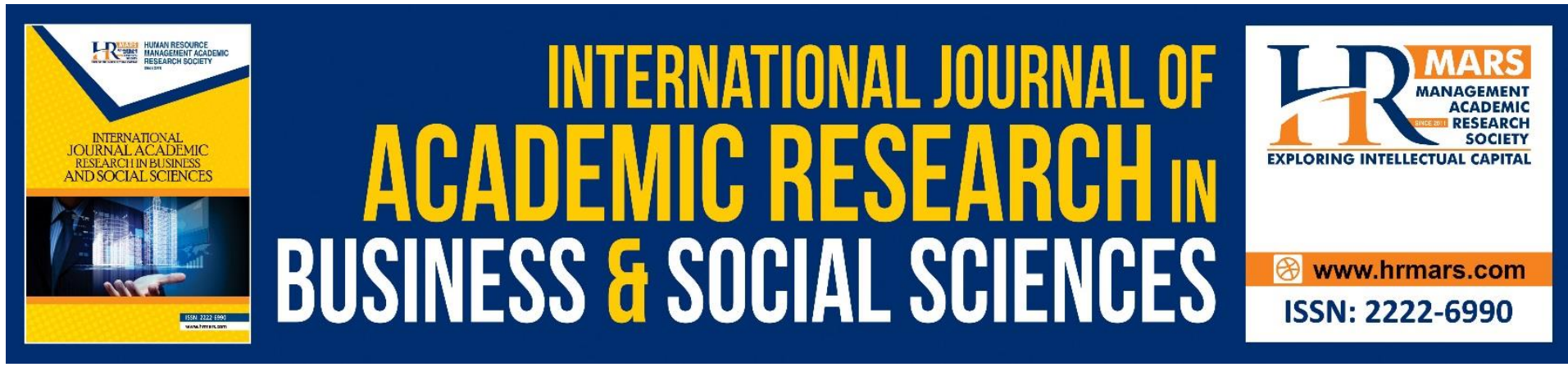

\title{
The Influence of E-Service Quality Toward Online Shopping Behaviour Amongst UiTM Students in Malaysia
}

\author{
Rozita Mengen, Mohd Safwan Ramli, Nur Hidayah Ayob, \\ Zaidatul Nadhirah Roslan \\ Faculty of Business and Management, Universiti Teknologi MARA (UiTM) Jengka, Pahang, \\ Malaysia \\ Email: safwanramli@uitm.edu.my,hidayahayob@uitm.edu.my
}

\begin{abstract}
Situations like pandemic (Covid-19) has bring about the rise of online shopping businesses. Online shopping is an electronic business that requires clients to buy goods and services entirely from sellers over the Internet via a search engine. Online shopping is the easy solution for busy and constrained life in today's world. Despite consumers' continuation to buy from a physical store, more users or buyers feel very convenient to online shopping. This research was conducted to examine the effects of e-service quality dimension (perceived value, firm reputation, privacy, trust, functionality) toward online shopping behaviour. Snowball sampling technique was applied and distributed to online shoppers via e-survey (google forms) within the period of two month. Analysing 303 data collected from online shoppers, the results have shown that perceived value is the most influential dimension of eservices quality towards online shopping behaviours among online shoppers in Malaysia. The recommendations are discussed in detail in the paper.

Keywords: E-Service Quality, Online Shopping Behaviour, Perceived Value, Firm Reputation, Privacy, Trust, Functionality

\section{Introduction}

In this age of globalization, the Internet expanded exponentially across the globe. According to the Statistics Site in 2019, there were 4.13 billion internet users around the world, indicating that more than half of the world's population already has Internet access. However, although the digital population in many parts of the world is growing noticeably, internet connectivity and availability can vary considerably according to the region (Internet Usage Worldwide, 2020). The usage of the Internet improved because of critical easy information distribution platforms that provide consumers with more search opportunities in the shortest possible period. Online shopping uses the Internet for several purposes. Online purchasing unlocks new windows where the well-known business-to-consumer (B2C) is used to purchase and sell goods electronically via the individual advantages of internet technologies (Farah, Ahmad, Muqarrab, Turi \& Bashir, 2018).
\end{abstract}


Online shopping is an electronic business that requires clients to buy goods and services entirely from sellers over the Internet via a search engine. The most common way for online shopping has been part of the millennial century which was hit straight via an acceleration in Web (Kumar, 2016). In all countries of the world, digital shopping is becoming very common (Al-Maghrabi, Dennis, \& Halliday, 2011). In Malaysia, this pattern is also too open to shopping on the Internet.

Nowadays, the Internet is a worldwide medium of transaction for customers rather than a networked newspaper (Nuruddin \& Abdullah, 2019). Ozen and Engizek (2014), as the Internet evolves rapidly, online shopping is becoming an immensely common way to buy all around the world. The share of customers engaged in online purchases and transactions has gradually grown.

Online shopping is a quick way to acquire goods, contrasted with traditional retail, to allow consumers to procure the necessary products without driving, traffic or parking while stopping fuel and charging (Huseynov \& Yildirim, 2016). Najihah, Lukman, Kamal, Azlini, and Normala (2018) say that customers can save time and order goods at any time and everywhere using this digital business method. Most of the other benefits of online shopping are that users may create a price analysis and take advantage of the deals they can buy from the convenience of their device or tablet; store anywhere stage (Abd Aziz \& Abd Wahid, 2018). In view of certain online ordering benefits, online shoppers will not see, contact, and smell the items until they vote to purchase. They thus also seem to experience a greater level of risk (Al-Debei, Akroush, \& Ashouri, 2015).

Not only is the millennial generation comfortable with e-commerce, but they are also still willing to get knowledge quicker. Therefore, nowadays, internet customers appear to be a younger audience (Chai et al., 2018). Individual purpose and behaviour of online shopping are extensively documented in developed countries. In developed countries such as Malaysia, however, there is a lack of studies in which internet shopping is progressively common among university students (Farah et al., 2018).

\section{Online Shopping in Malaysia}

Online shopping in Malaysia is a ground-breaking technology since Malaysia's retail industry has recently started to attack online shopping services (Noor et al., 2020). Online shopping and the internet are most prominent in university students in the age range 18-30 years old, although they don't have enough shopping funds. Nevertheless, university students find on top of the internet and have a firm intention of shopping online (Farah et al., 2018).

To increase online shopping in Malaysia, customer preferences and factors affecting this behaviour should be highlighted while shopping online. Farah, Ahmad, Muqarrab, Turi and Bashir (2018) notes that online shopping required more consumer intent than physical transactions. While the online shopping market's rapid growth promises future growth, negative factors have emerged in the conventional shopping system. Inadequacy of visual interaction or physical presence of the product is very dominant in online shopping and does not encourage the method of online shopping (Lim et al., 2016). As supported by Arfah (2017), the consumer does not have faith in buying online from the website. Due to concerns as to the transaction ability and payment procedures, these transactions are undeniable because any payment transaction is online and not through the counter that customers will hesitate to begin their payment process. Besides, poor website design also affects customers' purchasing intentions, especially newcomers. Approximately $82 \%$ of online customers left the 
website without completing their transactions due to weak website design features (Kartini et al., 2018). All these variables show that customers need to research the e-service quality dimensions that influence online purchasing intention.

Besides, perceived behaviour-control constraints can restrict online shopping choices. It is necessary to clarify human actions to a person wishing to perform some action because the surroundings prevent the act from being performed. In addition, certain obstacles led to Malaysians' reluctance to purchase online due to fear that others would be stolen or misused their personal information. Although Malaysia has strong potential for online shopping, there is indeed a poor understanding of online shopping and its impact on marketing (Noor et al., 2020).

In addition, customers often have difficulty logging into the account, and product information is limited and difficult to contact online sellers by phone. One study showed that $71 \%$ of online shoppers in Malaysia seemed to regret their online purchases, $48 \%$ were dissatisfied with inaccurate expectations, $29 \%$ were disappointed with poor product quality, and $30 \%$ of Malaysians were unable to complete online purchases (Lim et al., 2016).

\section{Literature Review \\ Online Shopping Behavior}

Online buying behavior is a person's general perception and an appraisal of a product or service, leading to inadequate or good results. Online shopping consists of purchasing goods and Internet-based businesses (Rahman et al., 2018). The purchasing method does have a lot of behavioral, physical purchasing measures. There are five phases a typical way of online shopping. Once the customer initially recognizes his needs for a product or service, he searches for details. The customer compares the item with other available choices after collecting product details, choosing it according to its specifications and criteria for transactions to select items, and gains experience after buying (Herpen, 2016). Thus, because technology and business trend penetration have shifted online, it is crucial to study the actions. In the age of IT, the internet has created and opened new windows worldwide to use internet technology to purchase and sell goods digitally where physical participation is not necessary. The online shopping business is not a sales product secret, so it is essential to examine customer behavior towards online shopping and payment of items because there is no physical contact. The more an online company recognizes these consumers' perceptions, the more likely they are to attract and retain buyers. To better understand positive, stimulating factors and appealing consumer thoughts, businesses must recognize reasons that influence negative consumer feelings and behavior that can impede online shopping (Huseynov \& Yildirim, 2016). One study shows that while a webpage can draw the number of users, only around $3 \%$ of those visits lead to online shopping, and approximately $65 \%$ of the online ordering cart are discarded due to the completion of a purchase, according to another study (Hidayat, Mokhtar \& Katan, 2016). These things explain that most customers go to the internet browse online with intentions to buy in a more traditional, offline environment (Gao \& Su, 2017).

\section{Perceived Value}

Consumer perception represented its buyer evaluation of the functionality of goods centered on the understanding of what was gained and delivered (Pham, Tran, Misra, Maskeliunas \& Damasevicius, 2018). The customer's perceived value is described as an overall measure of a trade-off between the apparent performance of the goods or service obtained 
and the overall development or service acquisition expense (Katta \& Patro, 2020). Argue that meaning perceived is a term that blends the shopping value with the commodity value (Fang, Wen, George \& Prybutok, 2016).

Besides, the interpretation of the value of customers would affect their propensity to revisit a product or service provider (Katta \& Patro, 2020). Study studies also showed that perceived worth could be better than happiness or efficiency than an indicator of repurchase intention (Pham et al., 2018). Chen, Tsai and Hsieh (2017) concluded that, among other considerations, perceived benefit is positive for buying plans. In Pham, Tran, Misra, Maskeliunas and Damasevicius (2018), studies have shown that consumers are prepared to accept more incredible prices to get the customer's services at a lower price in return for the reliability or lose convenience, which will boost its perceived value.

$\mathrm{Hu}$ (2011) showed that perceived worth greatly affected consumer loyalty, and both of them were significant customer buy intent predictors. An extensive study indicates the consumer importance viewed as a strong indicator of customer behavioral intentions and consumer loyalty (Tran \& Le, 2020). Hsu, Chang and Chuang (2015) indicated that online shopping's relative importance is a significant precedent of satisfaction. Researchers have shown that perceived worth was not just an immense context with behavioral motives while also being a modern model that provides a somewhat holistic view than a primary emphasis on the standard of service or satisfaction (Tran \& Le, 2020).

\section{Firm Reputation}

Firm reputation is a perception by customers of how much a company care for customers and their wellbeing (Farah, Ahmad, Muqarrab, Turi \& Bashir, 2018). Farah, Ahmad, Muqarrab, Turi and Bashir (2018) also found that corporations' excellent reputation offers a "buffering effect" to shield them from some of the adverse effects of a loss. While Kidane and Sharma (2016) described a company's credibility as the impression of clients, which is how well a company looks after clients and contributes to their prosperity. Firm reputation is also described as collective views, opinions and attitudes of customers towards the business (Jung \& Seock, 2016).

Several studies show that corporate reputation for Internet shopping is a determining factor in trust (Kidane \& Sharma, 2016). If the company's perceived reputation is positive, customers will have greater confidence in corporate advertisements. Researchers have noted that a good reputation enhances customer buying intentions, attitudes toward business and goods as well as customer loyalty (Jung \& Seock, 2016). However, researchers find negative knowledge more accurate and relevant than optimistic customer decisions (Jung \& Seock, 2016). In the current market scenario, customers prefer to rely on company and product knowledge to minimize risk when making purchasing decisions, and negative corporate credibility can outweigh a positive reputation.

\section{Privacy}

Privacy is the right of individuals, groups, or agencies to decide for themselves how, when and to what degree their knowledge is transmitted to others. However, this term does not consider a major contribution in the decision-making of privacy which is the security of information is dependent on a range of business practices which can vary from regular offline shopping to online shopping (Raman \& Pramod, 2015). Moreover, privacy information is also referred to as the right of a person to monitor the storage and use of personally identified personal information. Consumers' privacy issues typically emerge from three major aspects, 
which are the processing of sensitive data, authority over the use of personal information by companies, and knowledge of privacy policies and the use of personal data (Inman \& Nikolova, 2017). Privacy indicates how confidential and secure the information of customers is to the point that the online shopping website proves to be. In addition, due to its complexity, the capacity of new technology has improved with regard to the information collection, making privacy a major concern (Farah, Ahmad, Muqarrab, Turi \& Bashir, 2018). Privacy plays a significant part in gaining online shopping satisfaction and plays an important role in obtaining trust in online shopping. Since people are interested in purchasing online, they still have a privacy concern, so they lose faith in the company. In addition, privacy has a positive effect on confidence in online shopping (Ali et al., 2016)

\section{Trust}

Trust is characterized as a binding force in the online shopping process between buyer and seller (Khan et al., 2015). Trust is established through the relationship between parties that comprises assets of a trustee, qualities of a trustee, and a particular background for the transfer of trust (Chen \& Wu, 2017). Trust makes it comfortable for customers to share their details, buy and act on online sales consultancy, and all activities crucial for the general adoption of electronic commerce. Trust is linked to security. Purchasers cannot see items individually as they inquire and cannot inspect the salesperson's eyes while doing so. Businesses must create trust among their purchasers to prevent vulnerabilities. They must retain their ultimate objective. Online transactions usually require two forms of trust: confidence in transaction integrity (behavioral risk) and confidence in transaction support infrastructure (environmental risk) (Xu \& Jackson, 2019). Nguyen \& Khoa (2019) stated that online seller's trust positively impacted customer attitudes towards the online seller, which affected their willingness to purchase. As online shopping includes Internet purchases, all inherent risks associated with Internet use, such as online fraud, data protection, security problems, etc., become essential. The inability to communicate with the seller accentuates the user's sense of fear and anxiety. Online users have no trust in the money and personal information of Internet vendors (Ariffin \& Goh, 2018).

\section{Functionality}

Functionality is linked to the extent to which the website contains adequate detail about the products/services being marketed. The functionality of the website is described as the provision of a timely, reliable and effective online information delivery method. A website can be the only place that an online retailer can connect to its customers (Farah, Ahmad, Muqarrab, Turi \& Bashir, 2018). The functionality of the website shows the degree to which the website functions in the way it is designed and is supposed to behave as a customer's wish (Tandon, Kiran \& Sah, 2018). The functionality of the website requires accessibility and interactivity aspects which is refers to the ease of access as well as interaction to the web, responsiveness, and ease of navigation. Besides, in the online shopping environment, the reliability of the website components can be calculated by observing the browsing, purchasing and information functionality of the website as well as the speed at which certain operations and procedures can be carried out (Al-Debei, Akroush \& Ashouri, 2015). Therefore, this indicates that preserving the quality of website functionality is essential to attract and make customers revisiting, effectively ensuring customer loyalty to browse the websites (Jeon \& Jeong, 2017). 


\section{Conceptual Framework}

Figure 1 depicts the framework for the study adapted from Shirin and Mutambala (2015) under the title "consumers' online purchase intention in cosmetic products" an empirical study in an emerging market, the e-service quality could increase the online purchase intention by striving to improve the consumers' and other related factors in online purchase intention should be examined and suggests that the site design quality seems to be an important factor.

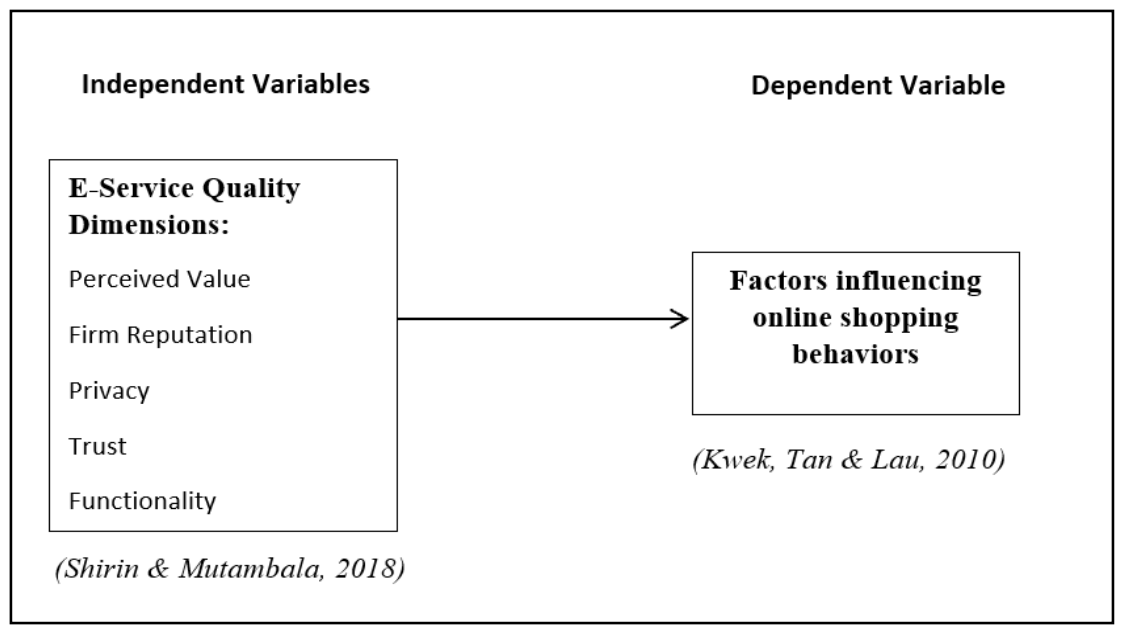

Figure 1: Conceptual Framework

\section{Research Questions}

Three research question are formulated in the study namely:

1. What is the level of online shopping behaviour among students?

2. What is the relationship between e-service quality and online shopping behaviour among students?

3. Which dimensions of e-service quality predict online shopping behaviour among students?

\section{Methodology}

The population of the study was Klang Valley respondents and the sample size were determined using GPower calculation. Based on the effect size of 0.15 , alpha level of 0.05 and five predictors, a total of 92 sample was suggested. However, according to Hair et al. (2014) the larger sample size improves precision and reliability. Furthermore, correlational research was adopted for this study. In addition, Snowball sampling technique was applied. The questionnaire was sent to respondents via WhatsApp and social media platform. The item for this study was adopted from past study; Arridha, Mohammed, Hazura, Elias, and Fazidah (2014). Some modifications were made to ensure the item meet with the context of the study and the item were validate by the field of experts.

\section{Findings and Discussions}

In this study, the data was obtained from 303 respondents. A total of 241 respondents $(79.5 \%)$ are female, and 62 respondents $(20.5 \%)$ are male. Pertaining to the age distribution of the respondents, $87.1 \%$ is in the age group between 18 until 30 years old, and 39 respondents (12.9\%) were aged between 31 until 40 years old. The most favourite shoppers' 
website is Shopee with 164 (54.1\%) respondents followed by Lazada with 139 (45.9\%) respondents.

Table 1: Demographic Details

\begin{tabular}{|c|c|c|c|}
\hline Demographic Details & Description & Frequencies & Percentage \\
\hline \multirow[t]{2}{*}{ Gender } & Male & 62 & 20.5 \\
\hline & Female & 241 & 79.5 \\
\hline \multirow[t]{2}{*}{ Age } & $18-30$ years old & 264 & 87.1 \\
\hline & $31-40$ years old & 39 & 12.9 \\
\hline \multirow[t]{4}{*}{ Income } & Below RM999 & 22 & 10.2 \\
\hline & RM1000 - RM1999 & 7 & 3.2 \\
\hline & RM2000 - RM2999 & 173 & 80.1 \\
\hline & RM3000 - RM3999 & 14 & 6.5 \\
\hline Shoppers & Shopee & 164 & 54.1 \\
\hline Website & Lazada & 139 & 45.9 \\
\hline
\end{tabular}

$R Q$ 1: What is the level of online shopping behavior among shoppers?

Descriptive statistics were computed for both independent and dependent variables in order to compare the level of e-service quality among online shoppers. The data were split into two different E-commerce website to comparison between the level of online shopping behaviours between both Shoppers website. The interpretation of the scores were based on the Best Principle (Thaoprom, 2004). Scores were divided by three ranges which are high, average and low with the computation like this: $5-1 / 3=1.33$.

Thus, the results are:

- Scores between 1.00-2.33 = Low Scores

- Scores between 2.34-3.67 = Moderate Scores

- Scores between 3.68-5.00 = High Scores

The assessment on the level of e-services quality for online shoppers revealed that as indicated in Table 2. It was found that for one dimension that only had moderate level and for shopee all dimensions of e-services quality level are in the range of high scores. That indicated that the level of dimension is high. 
Table 2: Level of E-Service Quality Among Online Shoppers

\begin{tabular}{llllll}
\hline $\begin{array}{l}\text { E-Commerce } \\
\text { Website }\end{array}$ & Variable & N & Mean & $\begin{array}{l}\text { Std } \\
\text { Deviation }\end{array}$ & Level \\
\hline & Perceived Value & 164 & 2.7485 & .41952 & Moderate \\
\hline Shopee & Firm Reputation & 164 & 3.7957 & .65313 & High \\
\hline & Privacy & 164 & 2.7119 & .62391 & High \\
\hline & Trust & 164 & 3.6189 & .75253 & High \\
\hline & Functionality & 164 & 4.1463 & .68028 & High \\
& $\begin{array}{l}\text { Overall E-Services } \\
\text { Quality }\end{array}$ & 164 & 4.3278 & .60134 & High \\
& $\begin{array}{lllll}\text { Overall Online } \\
\text { Shopping Behaviors }\end{array}$ & 164 & 4.5107 & .43021 & High \\
& Variable & $\mathbf{N}$ & Mean & Std & Level \\
\hline & Perceived Value & 139 & 4.0468 & .90268 & High \\
\hline & Firm Reputation & 139 & 4.1043 & .44222 & High \\
\hline Lazada & Privacy & 139 & 4.2230 & .95681 & High \\
\hline & Trust & 139 & 4.5863 & .49335 & High \\
\hline & Functionality & 139 & 4.6787 & .61896 & High \\
\hline & $\begin{array}{l}\text { Overall E-Services } \\
\text { Quality }\end{array}$ & 139 & 4.3278 & .60134 & High \\
\hline & $\begin{array}{l}\text { Overall E-Services } \\
\text { Quality }\end{array}$ & 139 & 4.7320 & .55710 & High \\
\hline & & & & \\
\hline
\end{tabular}

The findings based on the online shoppers in Malaysia have been supported by various online shopping behavior studies. According to Tajeddini, Altinay and Ratten (2017) and Ali (2019), reported that the way e-services quality and online shopping market's rapid growth promises future growth, positive factors have emerged in the conventional shopping system. Inadequacy of visual interaction or physical presence of the product is very dominant in online shopping and does not encourage the method of online shopping (Lim, Abdullah, Shahrul, Abdul, \& Safizal, 2016). As supported by Sharifah Arfah (2017), the consumer does not have faith to buy online from the website. Due to concerns as to the transaction ability and payment procedures, these transactions are undeniable because any payment transaction is online and not through the counter that customers will hesitate to begin their payment process.

\section{RQ 2: What is the level of online shopping behaviour among shoppers?}

Table 3 illustrates the relationship between independent and dependent variables which will be interpreted by using Cohen (1988) guidelines positive relationship between independent variable and dependent variables. Correlational analysis was conducted to determine the relationships between dimensions of e-services quality and online shopping behaviours. The findings are tabulated in Table 2 which will be interpreted according to the guidelines by Cohen (1988). It was discovered that all five dimensions of e-services quality had significant and positive relationships with online shopping behaviours. In fact, perceived value, firm reputation, privacy, trust and functionality were found to have positive relationships with online shopping behaviour $(r=.392, p, p<0.01 ; r=.681, p<0.01 ; r=.448$, 
$p<0.01 ; r=.764, p<0.01, r=.846, p<0.01$ respectively). These positive relationships have signified that the greater the perceived value, firm reputation, privacy, trust and functionality, the greater the online shopping behaviour among online shoppers. These findings are supported by Tajeddini, Altinary, Ratten, (2017) who found that e-services quality may affect both online shopping behaviours among online shopper among Malaysian. Whether it is shopping or travelling, it can be concluded that consumers are very particular about service quality aspect especially if they want to continuously use certain platform as their main medium of purchasing or information search.

Table 3: Correlation Between E-Services Quality and Online Shopping Behaviors

\begin{tabular}{|c|c|c|c|c|c|c|}
\hline & 1 & 2 & 3 & 4 & 5 & 6 \\
\hline Perceived Value & 1 & $.311^{* *}$ & $.943^{* *}$ & $.657^{* *}$ & $.536^{* *}$ & $.392 * *$ \\
\hline Firm Reputation & $.311^{* *}$ & 1 & $.307 * *$ & $.665^{* *}$ & $.860 * *$ & $.618^{* *}$ \\
\hline Privacy & $.943 * *$ & $.307^{* *}$ & 1 & $.755^{* *}$ & $.485^{* *}$ & $.448 * *$ \\
\hline Trust & $.657^{* *}$ & $.655^{*}$ & $.755^{* *}$ & 1 & $.765 * *$ & $.764 * *$ \\
\hline Functionality & $.536 * *$ & $.860 * *$ & $.485^{* *}$ & $.765^{* *}$ & 1 & $.846 * *$ \\
\hline $\begin{array}{l}\text { Online } \\
\text { Behaviors }\end{array}$ & $.392 * *$ & $.681^{* *}$ & $.448^{* *}$ & $.764 * *$ & $.846^{* *}$ & 1 \\
\hline
\end{tabular}

${ }^{* *}$ Correlation is significant at the 0.01 level ( 1 tailed)

$R Q$ 3: Which dimensions of e-service quality predict online shopping behaviour among students?

Table 4 shows the results of multiple regression analysis in determining the predictors of e-services quality towards the online shopping behaviours among online shoppers in Malaysia. It was found that the R2 value was 0.785 in which all dimensions comprised of eservices quality are explained $78.5 \%$ of the variance for online shopping behaviours. The findings have shown that perceived value is the most influential dimension of e-services quality towards online shopping behaviours among online shoppers in Malaysia $(\beta=0.955$, $\mathrm{p}<0.05)$, however other the dimension such firm reputation, trust, functionality does not have influential toward online shopping behaviours among online shoppers. In the meantime, privacy dimensions were found to have negative influence towards the online shopping behaviours among online shoppers in Malaysia $(\beta=-0.207, p>0.02)$. Therefore, it can be concluded through these findings that only two out of five dimensions of e-services quality acted as predictors towards the study's dependent variable which is online shopping behaviours. As stated by Katta \& Patro (2020) and Hassan, Ayob, Sumardi, Ramli, Halif (2021) the interpretation of the value of customers would affect their propensity to revisit a product or service provider. 
Table 4: Multiple Regression Analysis Between Dimensions of E-Services Quality Towards Online Shopping Behaviors

\begin{tabular}{lllll}
\hline & Independent variables & Standardized Coefficients Beta & t & Sig. \\
\hline & Perceived value & .033 & 868 & .387 \\
\hline Lazada & Firm Reputation & -.388 & -9.588 & .000 \\
\hline & Privacy & -.112 & -2.031 & .044 \\
\hline Trust & .820 & 16.244 & .000 \\
\hline Functionality & .597 & 10.443 & .000 \\
\hline R Square & & .947 & \\
\hline F & & 565.028 & \\
\hline Sig. F Value & & .000 & \\
\hline Durbin Watson & & 2.134 & \\
\hline Independent variables & Standardized Coefficients Beta & $\mathbf{t}$ & Sig. \\
\hline & Perceived value & .975 & -9.933 & .000 \\
\hline Firm Reputation & -.215 & -4.630 & .000 \\
\hline Privacy & .681 & -3.508 & .000 \\
\hline Trust & -.222 & 19.769 & .001 \\
\hline Functionality & 1.453 & -32.420 & .000 \\
\hline R Square & & .927 & \\
\hline F & & 339.230 & \\
\hline Sig. F Value & & .000 & \\
\hline Durbin Watson & & .777 & \\
\hline
\end{tabular}

\section{Conclusion and Recommendations}

Based on the findings, it can be concluded that respondents believed that using eservices quality can influence online shopping behaviours. The results are split in to two which are Lazada and Shopee implied that among online shoppers in Malaysia purchase behaviours was influenced by functionality for both shoppers Lazada and Shopee. The result indicates that the functionality predicts the online purchase behaviours. For Lazada the least out of the five independent variables that are out of one variable do not have an influences on the online purchase behaviours and for Shopee all five independent variable had significant influence online purchase behaviour among shoppers however the are two variable that had negative significant relationship which are firm reputation and trust. For Lazada the relationship does not exist and the respondents' answers regarding the perceived value may have been somewhat neutral to a little positive. Companies should put their efforts in the into making it more valuable for customer to visit the website. In this study it has been recommended that perceived value, firm reputation, privacy, trust, functionality predicts the online shopping behaviour in among online shoppers should be look forward by e-commerce website. Thus, future study is suggested to select working adults and other variables that related to online shopping can be included. More in-depth and exactly what should do to develop is not dealt with in this study. it would be interesting to further investigate their online purchase intention. The researcher could conduct a qualitative research in order to gain a deeper understanding of their online behaviours and might also include variables such as online adoption and familiarity. It could also be interesting to investigate this study's independent variables: perceived value, firm reputation, privacy, trust, functionality separately in one study and to see the impact on the online shopping behaviours. That would 
also make it possible for the researcher to go in deeper in that chosen independent variable and detect what aspects of that independent variable is essential and why. In addition, moderating roles of demographics, diverse generations of $\mathrm{m}$-shoppers and market segmentation can be tested in future research studies. The extrinsic factor, such as the purchase situation can also be investigated as a mediator or moderator for the future.

\section{Limitation and Recommendation}

Limitations of this learn about include: (1) the respondents have been much less cautious in analysing the statement of the research as a supply of principal data, (2) Due to covid-19 there are less people whom able to answer the questionnaire at the study was conducting and distributing via Google form. Therefore, for in addition research for next time the researcher may entering the .

\section{Theoretical and Contextual Contribution}

This research has made significant contributions to the body of knowledge on factor influencing online shopping behaviours in the consumer in Malaysia. It has identified a list of factors as composite variables which are affecting the online shopping behaviours for implementing e-services quality in the study. On the other hand, from a theoretical perspective.

The present research contributes to the theoretical approach by proposing a conceptual framework with the adaptation of the Theory of Acceptance Model and the inclusion of perceived usefulness, convenience, trust, privacy, functionality, and firm reputations as variables to analyse customer attitude and customer online purchase intention during the Covide-19 Pandemic. Previous researchers did adopt the theory of acceptance model in online purchase yet scarce research has been conducted in the era of Covid-19 where the tendency of online purchase increased simultaneously with the government restriction and fear of covid-19. The findings provided a better understanding of customer online intention. Besides the theoretical contribution, the current study provides practical implications for marketers to promote online shopping and increase customer purchase intention. The findings show that, perceived usefulness, convenience, trust, privacy, functionality, and firm reputations are important factors that affect customer attitude and purchase intention. Therefore, online platform developers should invest in online platform functionality by providing attractive colour schemes, proper taglines, guidance to emphasize the appeal of the platform for visual and make it more convenient and easier to use.

\section{References}

Abd Aziz, N. N., \& Abd Wahid, N. (2018). Factors influencing online purchase intention among university students. International journal of academic research in business and social sciences, 8(7).

Al-Debei, M. M., Akroush, M. N., \& Ashouri, M. I. (2015). Consumer attitudes towards online shopping: the effects of trust, perceived benefits, and perceived web quality. Internet Research.

Ali, A., \& Yousuf, S. (2019). Social capital and entrepreneurial intention: Empirical evidence from rural community of Pakistan. Journal of Global Entrepreneurship Research, 9(1), 1-13. 
Ali, N. I., Samsuri, S., Sadry, M., Brohi, I. A., \& Shah, A. (2016). Online shopping satisfaction in Malaysia: A framework for security, trust and cybercrime. In 2016 6th International Conference on Information and Communication Technology for The Muslim World (ICT4M) (pp. 194-198). IEEE.

Al-Maghrabi, T., Dennis, C., \& Halliday, S. V. (2011). Antecedents of continuance intentions towards e-shopping: the case of Saudi Arabia. Journal of Enterprise Information Management.

Ariffin, S. K., Mohan, T., \& Goh, Y. N. (2018). Influence of consumers' perceived risk on consumers' online purchase intention. Journal of Research in Interactive Marketing.

Chai, K. Y., Lee, Y. W., Peh, J. T., \& Yap, H. Y. (2018). Factors influencing the online shopping behavior of students in UTAR, Kampar Campus (Doctoral dissertation, UTAR).

Chen, H. S., Tsai, B. K., \& Hsieh, C. M. (2017). Determinants of consumers' purchasing intentions for the hydrogen-electric motorcycle. Sustainability, 9(8), 1447.

Chen, P. Y., Chen, K. Y., \& Wu, L. Y. (2017). The impact of trust and commitment on value creation in asymmetric buyer-seller relationships: the mediation effect of specific asset investments. Journal of Business \& Industrial Marketing.

Cohen J, (1988). Statistical power analysis for the behavioral sciences. 2nd ed. Hillsdale, New Jersey: Erlbaum.

Fang, J., Wen, C., George, B., \& Prybutok, V. R. (2016). Consumer heterogeneity, perceived value, and repurchase decision-making in online shopping: The role of gender, age, and shopping motives. Journal of Electronic Commerce Research, 17(2), 116.

Farah, G. A., Ahmad, M., Muqarrab, H., Turi, J. A., \& Bashir, S. (2018). Online shopping behavior among university students: Case study of Must University. Advances in Social Sciences Research Journal, 5(4), 228-242.

Gao, F., \& Su, X. (2017). Online and offline information for omnichannel retailing. Manufacturing \& Service Operations Management, 19(1), 84-98.

Hassan, Ayob, Sumardi, Ramli, Halif. (2021). The influence of service convenience towards consumer continuance usage intention. Psychology and Education Journal, 58(1), 3936-3945.

Hidayat-ur-Rehman, I., Mokhtar, S. A., \& Katan, H. (2016). An empirical analysis of consumers' continuance intention towards online shopping. Mediterranean Journal of Social Sciences, 7(5), 95.

Hsu, M. H., Chang, C. M., \& Chuang, L. W. (2015). Understanding the determinants of online repeat purchase intention and moderating role of habit: The case of online groupbuying in Taiwan. International Journal of Information Management, 35(1), 45-56.

$\mathrm{Hu}, \mathrm{Y}$. (2011). Linking perceived value, customer satisfaction, and purchase intention in ecommerce settings. In Advances in computer science, intelligent system and environment (pp. 623-628). Springer, Berlin, Heidelberg.

Huseynov, F., \& Yıldırım, S. Ö. (2016). Internet users' attitudes toward business-to-consumer online shopping: A survey. Information Development, 32(3), 452-465.

Inman, J. J., \& Nikolova, H. (2017). Shopper-facing retail technology: A retailer adoption decision framework incorporating shopper attitudes and privacy concerns. Journal of Retailing, 93(1), 7-28.

Jeon, M. M., \& Jeong, M. (2017). Customers' perceived website service quality and its effects on e-loyalty. International Journal of Contemporary Hospitality Management.

Jung, N. Y., \& Seock, Y. K. (2016). The impact of corporate reputation on brand attitude and purchase intention. Fashion and Textiles, 3(1), 1-15. 
Naradin, K. D., Hairuddin, H., Ab Malik, A. M., \& Kassim, S. E. (2018). Online purchase intention: explorations of the Facebook users' psychological factors. Advances in Business Research International Journal (ABRIJ), 4(2), 20-31.

Katta, R. M. R., \& Patro, C. S. (2020). Consumers' perceived value in internet shopping: an empirical study. International Journal of Customer Relationship Marketing and Management (IJCRMM), 11(2), 17-36.

Khan, F., Rasli, A., Yusoff, R., \& Isa, K. (2015). Impact of trust on online shopping: A systematic review of literature. Journal of Advanced Review on Scientific Research, 8(1), 1-8.

Kidane, T. T., \& Sharma, R. R. K. (2016). Factors affecting consumers' purchasing decision through ecommerce. In Proceedings of the 2016 International Conference on Industrial Engineering and Operations Management Kuala Lumpur, Malaysia (Vol. 8, No. 10, pp. 159-165).

Kumar, M. (2016). Consumer behavior and satisfaction in e-commerce: a comparative study based on online shopping of some electronic gadgets. Clear International Journal of Research in Commerce and Management, 7(7).

Lim, Y. J., Osman, A., Salahuddin, S. N., Romle, A. R., \& Abdullah, S. (2016). Factors influencing online shopping behavior: the mediating role of purchase intention. Procedia economics and finance, 35, 401-410.

Najihah, M. N., Lukman, Z. M., Kamal, M. Y., Azlini, C., \& Normala, R. (2018). Online shopping behaviours on apparel products among university students. International Journal of Research and Innovation in Social Science (IJRISS), 2(12), 45-48.

Nguyen, M. H., \& Khoa, B. T. (2019). Customer electronic loyalty towards online business: the role of online trust, perceived mental benefits and hedonic value. Journal of Distribution Science, 17(12), 81-93.

Noor, N. M., Noranee, S., Zakaria, M. F., Unin, N., \& Suaee, M. A. H. M. (2020). Online shopping: the influence of attitude, subjective norm and perceived behavioral control on purchase intention. In Proceedings of the 2020 The 6th International Conference on E-Business and Applications (pp. 33-36).

Nuruddin, N. Z. H., \& Abdullah, N. (2019). Customer digital shopping orientations and factors of digital shopping behavior in e-retailing shopping among the gen-y students. Journal of Contemporary Business, Economics and Law, Vol. 20(2).

Ozen, H., \& Engizek, N. (2014). Shopping online without thinking: being emotional or rational? Asia Pacific Journal of Marketing and Logistics.

Pham, Q. T., Tran, X. P., Misra, S., Maskeliūnas, R., \& Damaševičius, R. (2018). Relationship between convenience, perceived value, and repurchase intention in online shopping in Vietnam. Sustainability, 10(1), 156.

Rahman, M. A., Islam, M. A., Esha, B. H., Sultana, N., \& Chakravorty, S. (2018). Consumer buying behavior towards online shopping: An empirical study on Dhaka city, Bangladesh. Cogent Business \& Management, 5(1), 1514940.

Raman, R., \& Pramod, D. (2015). A study on user perception and awareness related to online privacy during online shopping. Journal of Theoretical \& Applied Information Technology, 77(3).

Sekaran, U., \& Bougie, R. (2016). Research methods for business: A skill building approach. John Wiley \& Sons.

Tajeddini, K., Altinay, L., \& Ratten, V. (2017). Service innovativeness and the structuring of organizations: The moderating roles of learning orientation and inter-functional coordination. International Journal of Hospitality Management, 65, 100-114. 
Tandon, U., Kiran, R., \& Sah, A. N. (2018). The influence of website functionality, drivers and perceived risk on customer satisfaction in online shopping: an emerging economy case. Information Systems and e-Business Management, 16(1), 57-91.

Thaoprom, P. (2004). Relationship between quality of work life and job performance for police office-crime prevention and suppression division: case study Thonglor Metropolitan (Doctoral dissertation, Mahidol University).

Van Herpen, E., Van den Broek, E., Van Trijp, H. C., \& Yu, T. (2016). Can a virtual supermarket bring realism into the lab? Comparing shopping behavior using virtual and pictorial store representations to behavior in a physical store. Appetite, 107, 196-207.

$\mathrm{Xu}, \mathrm{X} .$, \& Jackson, J. E. (2019). Examining customer channel selection intention in the omnichannel retail environment. International Journal of Production Economics, 208, 434445. 